\title{
Translation, Race, and Ideology in Oriki Orixá
}

\author{
Jonathan Fleck \\ University of Texas at Austin \\ jonathanfleck@utexas.edu
}

\begin{abstract}
In the midst of an influential career writing on Brazilian cultural production, the sociologist-turned-political marketer Antonio Risério publishes Oriki Orixá, a book of Portuguese re-translations of Yoruba oriki poetry (1996, reprinted 2013). Understanding translation as a partial and ideologically-motivated act of representation, the current article situates Oriki Orixá within an ideology of race in Brazil. I take into account textual and paratextual materials including the book's introduction by Augusto de Campos; the editorial promotion of the work; its circulation within a literary network; and the highly mediated histories of the source poems. Oriki Orixá simultaneously promises a universal poetic "invention" and an ethnographic "recuperation" of a foreign text. Ultimately, the white author frames his translation as an affective encounter with an African literary tradition. This encounter participates in - and reinforces - a discourse of racial exceptionalism in which an abstract celebration of African-European contact occludes continuing histories of domination and inequality.
\end{abstract}

\section{Keywords}

Brazil - translation - race - Yoruba poetry - retranslation

\section{Introduction}

Oriki Orixá (1996, reprinted 2013), Antonio Risério's book of Brazilian Portuguese translations of Yoruba oral poetry, is promoted as both an elite poetic innovation and as a recuperation of Brazil's African cultural heritage. In the introduction and on the back cover, the famed poet and literary translator Augusto de Campos says: "Assim como Eliot disse de Pound ser ele o inventor da poesia chinesa para o nosso tempo, podemos afirmar, guardadas as proporções, 
que Antonio Risério está inventando a poesia iorubá para nós"1 (Oriki Orixá 12, back cover). To promote Oriki Orixá's poetic re-creation of the oriki, Campos invokes T.S. Eliot's celebration of Ezra Pound's English translations of Classical Chinese poetry. While Campos indicates the text's high-modernist and avantgarde resonances, the editorial promotion characterizes the translation as the recuperation of Brazilian "roots:" "Ao final da leitura de Oriki Orixá, mais do que o resgate de uma tradição oral que se dilui fica a impressão de que Risério desentranha raízes fortes e secretas da cultura brasileira" ${ }^{2}$ (Editora Perspectiva n.p.). In the essays that accompany Oriki Orixá, the translator self-consciously taps into both modes of writing: an elite aesthetic of "invention" as well as the recovery of Afro-Brazilian cultural roots.

Beyond aesthetic readings of the text (see Padilha and White), the current article explores how the white translator's performed encounter with African poetry intersects with discourses of race in Brazil. ${ }^{3}$ As I will argue, the oscillation between invenção ("invention") and resgate ("rescue"/"recovery") entails complex strategies of translational domestication and appropriation. These strategies reflect what Alexandra Isfahani-Hammond terms "white negritude," or the tradition of metaphorically "Africanized" white authors positioning themselves as the exclusive mediators of Afro-Brazilian cultural forms (4). More generally, "white negritude" is a literary component of the contested ideology of democracia racial, which celebrates the biological and cultural mixture of Euro-descendants and Afro-descendants, while masking continued racial inequalities. Risério represents a prime example of the translator's complex positionality, as an "agent of translation" (Milton and Bandia). He holds sociopolitical authority within government and public debate. He is often quoted as an expert on race and society in national and international newspapers (Economist), and worked as a consultant to the Ministry of Culture (Gil). In the years following the publication of Oriki Orixá, he wielded influence in national politics as a marketer for the presidential campaigns of the Workers'

1 "Just as Eliot said that Pound was the inventor of Chinese poetry for our time, we can affirm, bearing in mind the proportions, that Antonio Risério is inventing Yoruba poetry for us" (all translations are my own unless otherwise noted).

2 "After reading Oriki Orixá, beyond the recovery [resgate] of an oral tradition that has been diluted, one has the impression that Risério uncovers the strong and secret roots of Brazilian culture."

3 Risério self-identifies as "white" and as "light-skinned mestiço," and indicates that he never experienced racial discrimination ( $A$ utopia 14). Race—and racial inequality-in Brazil is primarily constructed through phenotype, as opposed to the us model of identifying race in genealogy (Segato 108; Telles 1). 
Party (Partido dos Trabalhadores or $P T$ ) candidate Luiz Inácio Lula da Silva in 2002 and 2006, and for the first campaign of Dilma Rousseff in 2010. In keeping with its author's profile, Oriki Orixá illuminates translation as a locus of power, where the circulation of literary texts intersects with deep-seated discursive traditions in the receiving culture. Shifting from the aesthetic to the political and from the personal to the national, Oriki Orixá and its paratexts claim the authority to speak for Brazil's African heritage.

Risério doesn't speak Yoruba (Oriki Orixá 94), but draws his source texts from five previous translations published between 1957 and 1991. These "diverse poetic-anthropological works" (118) transcribe poems from religious ceremonies in Nigeria and Brazil, and translate the texts into English, French, or Brazilian Portuguese. From these books, Risério selects twenty-two poems or fragments to include in Oriki Orixá. Eleven of the source poems are from two books of Brazilian Portuguese translations by Síkírù Sàlámì: Mitologia dos Orixás africanos, published in 1990, and Cânticos dos Orixás na África, from 1991. Mitologia and Cânticos primarily address Brazilian candomblé devotees hoping to practice the religion more "authentically" (Sàlámì 9), with a secondary audience of scholars. ${ }^{4}$ Nine other poems are taken from the French ethnographer Pierre Verger's 1957 Notes sur le culte des Orisa et Vodun à Bahia: la Baie de tous les saints au Brésil et à l'ancienne côte des esclaves en Afrique. ${ }^{5}$ Verger documents ceremonies in Nigeria and Brazil, and translates an extensive corpus of Yoruba poetry into French. In addition to Sàlámì and Verger, one poem is drawn from the English anthropologist John Pemberton III's 1989 essay "The Dreadful God and the Divine King," and one from Judith Illsley Gleason's 1992 book Oya: In Praise of an African Goddess.

Risério's renderings of the oriki rely partly on the Yoruba transcriptions included with the previous translations, partly on dictionaries and anthropological studies, and partly on the previous translations themselves (Oriki Orixá 94). Thus, the versions found in Oriki Orixá are both "alternative" translations and re-translations, although the author emphasizes the former. Referring to word choice or translational "solutions," Risério claims: "I used very few [solutions] from the author-translators that I read. Those [solutions] are

4 Candomblé is a syncretic religion based in large part on African religions brought to Brazil via the slave trade. Iyakemi Ribeiro's introduction to Mitologia indicates that the text responds to the "desejo sincero de realizar o mais pura e autenticamente possível o que se nos afigurava como nosso trabalho espiritual" ("sincere desire to realize in the most pure and authentic way possible that which composed our spiritual work," 9).

5 Notes on the Cult of the Orishas and Vodun: From Bahia, the Bay of All Saints, Brazil and from the Ancient Slave Coast in Africa. 
exceptions-really" (96). Indicating Ezra Pound as a precursor who practiced creative translation without knowing the source language, Risério suggests that his renderings convey the poetic texture of the oriki more aptly than the previous translators were able to $(17,87) \cdot{ }^{6}$ In addition to the translations, Oriki Orixá contains chapters on African language, literature, and religion; the philosophy and methodology of translation; and the role of the oriki form in contemporary culture.

In the following pages, I will build on theories of translation as a partial and ideologically motivated act of representation in order to situate Oriki Orixá within the discursive tradition of democracia racial. I then analyze translational paratexts and accompanying materials that stage translation as a personal, affective poetic encounter with Yoruba aesthetics, an encounter that is then generalized to celebrate racial-cultural exchange on a national level, and that provide shifting definitions of the oriki, positing translation as an access to an oral aesthetic, while at the same time domesticating the poetry within a universalizing avant-garde project. I also track layers of dehistoricization in the textual circulation of the re-re-translation entitled "Ogum 1." In the conclusion, I argue that the case of Oriki Orixá illuminates wider questions of world literature, translation, and the cultural reinforcement of ideologies of race.

\section{Situating Translation within Democracia Racial}

As they circulate across borders, translations intervene in literary, discursive, and ideological networks. Beyond transferring aesthetic or communicative information, therefore, translators actively construct social meanings through a process that is "highly charged with significance at every stage" (Bassnett and Trivedi 2). Texts undergo layers of mediation in the selection of sources, the adoption of linguistic strategies, the intervention of patrons (Lefevere 10), and the circulation of products through marketing. In Oriki Orixá, an ethnographic pedigree for the translation is supplied by the translator himself. ${ }^{7}$

6 As in Campos's promotion, Risério justifies his linguistically precarious project by invoking Pound's Chinese translations: "Old Pound, far from being a sinologist, or of possessing even a reasonable knowledge of Chinese, knew how to bring to the community of English-language readers figures such as Bunno, Mei Shing and Li T’ai Po," (Oriki Orixá 95).

7 Risério has maintained a consistent voice in the scholarly and creative revalorization of Afro-Brazilian aesthetics since the 1970s. In his widely influential Carnaval Ijexá (1981), the author analyzes Afro-Brazilian cultural and textual production, especially during carnaval, 
Moreover, introductions, commentaries, and promotions constitute a text's "editorial and translatorial positioning" (Whitfield 89). This positioning can advance, often more clearly than the translator's microlinguistic choices, the ideological imperatives of a particular translation.

Maria Tymoczko describes translation as a form of representation shaped by the ideological context from which it emerges. As representations, translations are necessarily partial and motivated by extra-textual concerns: they involve "perspectives and (sometimes hidden) agendas, [and] they also reflect and are structured by preexisting discourses that inform the views of those making the representations" (Tymoczko 113). Not only do translations take form within the discursive traditions of the receiving culture, but they also actively intervene in ideological polemics. Similar to the ethnographer, the translator puts forth "a claiming of authority" and "an appropriation of the right to speak for another culture" (114). Methodologically, therefore, the critical study of translation expands beyond a words-on-the-page reading in order to interrogate the wider discourses that explicitly or implicitly frame texts.

As a partial representation of an African poetic tradition, Oriki Orixá reveals a locus of intersection- "a site where discourses meet and compete" (Tymoczko and Gentzler xix) - for aesthetics, cultural appropriation, and race. The socio-political power of this representation becomes apparent when Oriki Orixá is situated within the discourse of democracia racial in Brazil. Democracia racial can be traced back to the Brazilian sociologist Gilberto Freyre; in particular, his 1933 treatise on Brazilian race relations The Masters and the Slaves (Casa-grande \& senzala, trans. Samuel Putnam). In The Masters, Freyre portrayed affective ties, physical proximity, and cultural and biological miscegenation between masters and slaves in Brazil. For Freyre, these connections between the masters and the slaves counteract - or have already overcomeracial prejudice. In other words, miscegenation has led Brazil to "the point when one half of his [a nation's] personality no longer endeavors to suppress the other half" (349), referring to white and black "halves" respectively. Freyre's idealization of race relations is contingent upon a discourse of affect. Anna M. Klobucka argues that The Masters and Freyre's later texts reinforce a "tradition of infusing the representations of Lusophone colonialism and postcolonialism with postulations of affect as a centrally operative force" (40). A suggestion of a quasi-familial relationship between masters and slaves allows the

and tracks the rise of black consciousness in Bahia. In the following decades, he publishes Avant-garde na Bahia (Avant-Garde in Bahia, 1995) and Uma história da cidade da bahia (A History of the City of Bahia, 2004), offering a remarkable review and analysis of creative output in an environment of bold cultural fusion in Salvador, Bahia from the 1950s to the 1970s. 
discourse of democracia racial to elide the stark asymmetries that have characterized historical and contemporary race relations.

The descriptive power of democracia racial has been challenged and debunked since The Masters; however, the underlying affective rhetoric has survived in the form of ideology. Beginning in 1950, a UNESCO research project revealed widespread racial prejudice and socio-economic inequalities in Brazil. Although the researchers had expected to find an exemplary model of harmony, this idealized view was countered by the sobering realization that "Brazil had failed to elude racial discrimination" (Maio). Despite the evidence against Brazil's racial exceptionalism, the image of democracia racial continued to operate. As António Sérgio Guimarães points out, while few informed people still hold onto democracia racial as an accurate depiction of Brazilian society, the myth has come to be reformulated "as an atemporal and a-historic value" (19). As it has continued to structure many debates on race at the national level, Abdias do Nascimento suggests that the myth of racial democracy "has become one of the most deeply engrained elements of the Brazilian social consciousness" (viii). As ideology took the place of description, an abstract celebration of harmony has been severed from the historical reality of racial domination.

The Brazilian discourse of racial exceptionalism finds a reflection in literary texts, through the tradition of "white negritude." Tracing the literary underpinnings of democracia racial, Isfahani-Hammond deconstructs the "commonsense" validity of the white mediation of Afro-Brazilian cultural forms, and analyzes how acts of appropriation hide power asymmetries. In texts such as Jorge de Lima's 1947 Poemas negros (Black Poems), a rhetorical appeal to affect, and a preference for Afro-Brazilian sensory referents, justifies the white author's assumption of the role of mediator of black culture. In this way, authors supported a wider social discourse that celebrates the "survival" of African forms in Brazil, while denying the agency of Afro-Brazilian populations through a "containment of Brazilian blackness" (Isfahani-Hammond 46). Although Oriki Orixá appears half a century after Poemas negros, in the next section I argue that Risério's treatment of Yoruba poetics performs a function akin to the texts of "white negritude." An affective vocabulary of African encounter paradoxically appears within a dismissal of black activism.

\section{Affect and Nation: Translation as Resgate}

Oriki Orixá draws from the discursive tradition of democracia racial, in which an affective ideology of racial contact elides a deep-seated hierarchy, and a highly personal encounter with African poetry comes to uphold a dehistori- 
cized vision of race relations in the national sphere. In order to explore this dynamic, I turn to two of the translation's paratexts: Risério's reflections on translating the oriki within his original poetry (Fetiche, [Fetish], 1996), and his reference to Yoruba language in his treatise on race relations (A utopia brasileira e os movimentos negros, 2007). These paratexts activate translation as a discursive hinge for poetics and race, as the author's translational encounter with Yoruba poetry provides an affective vocabulary for an intervention into the politics of racial construction.

The author links translation, affect, and national race relations through the Yoruba word padê, which describes the action of "meeting" or "encountering." Padê appears in both Fetiche and A utopia brasileira, two seemingly disparate works. In the former text, the Yoruba term expresses the translator's affective encounter with the oriki, staged in a poem entitled "Padê." The poem dramatizes an exchange between a Portuguese-language translator and an African "queen" identified with the orixá Oiá-Iansã. In an author's note to the poem, Risério references his experience translating Yoruba poetry into Portuguese, and imagines translation as a personal encounter with the African forms. The poem's title was inspired by his experience translating oriki: "I employ the word 'padê' ... in the sense of encounter (crossroads, reunion, meeting point)," reflecting "my relations with Yoruba poetry and language" (Risério Fetiche 101, "meeting point" in English in original). The titular "Padê" signifies a conceptualaffective space in which the poet "relates" to the Yoruba tradition through translation.

In A utopia brasileira, Risério draws from a large corpus of primary and secondary texts to counter what he sees as an increasing trend of politically-correct reductionism in "the discussion of the Brazilian race question" (9). Such exaggerated "racialism" (10), as the author puts it, is the unfortunate product of North American academic imperialism. The universalization of North American social constructs has seduced Brazilian black movements into adopting a U.S.-style binary construction of race that categorically separates "white" from "black." Objecting to black activists and scholars such as Nascimento (53), Risério dismisses the austere binary model, or its strategic cultural translation, in favor of the "rich Brazilian chromatic spectrum" (411).

To argue for his view of Brazilian race relations, Risério invokes padê. After reviewing etymological, liturgical, and cultural explanations of the Yoruba word, the author asserts padê in opposition to apartheid: "Well, padê and apartheid are expressions that I utilize to characterize aspects of Brazilian and North American racial experiences" (11). Racial separation contrasts with celebration: while "apartheid speaks to us of separation, padê speaks to us of encounter, reunion, celebration." The author's choice of a Yoruba term to 
encapsulate his vision of Brazilian race relations ostensibly circumvents Eurocentric modes of describing cultural dynamics. However, padê in A utopia brasileira is mobilized to invalidate activist cultural translation by positing a mode of race relations premised on "encontro, reunião, festa." The metaphor of padê is overdetermined as an affective space of translation and as an emblem for Brazilian race relations more generally.

In their reading of $A$ utopia brasileira, Ella Shohat and Robert Stam analyze a dehistoricizing trend that upholds cultural linkages as the counter to sociopolitical differences: “'African' for Risério means acarajé, capoeira, and the orixás" 8 (Shohat and Stam 190). In other words, many of Risério's claims are "premised on a separation between culture and history" (191). Shohat and Stam demonstrate the political stakes of the cultural translation of concepts of race. As the paratexts to Oriki Orixá show, moreover, literary translation occupies a central position in the slippage between a discourse of personal affect and commentary on race relations in the nation. For the translator, poetic affect and national racial contact run the same vector and require the same terminology, reflecting a discursive tradition of affect as the Lusophone mode of contact between whites and blacks (Klobucka 40).

\section{An Oral Ideogram? Translation as Invenção}

As world texts circulate through multiple languages and geographies, a receiving culture can "impose domestic literary values on the foreign work" (Damrosch 4). The "domesticating" power of translation, moreover, can support dominant socio-cultural interests in the receiving culture as translation works to construct the foreign. Translations can, in other words, at once enact and mask "an insidious domestication of foreign texts" (Venuti Translator's 17). Elements of the source text may be adjusted to fit within the assumptions of a target culture, thereby domesticating potentially subversive narratives. Translators can also erase the historical geneses and contestations of texts, disregarding the subjectivities and interventions of textual circulation in favor of an assumption of "transcendental subjectivity and transparent communication" (39). Such ideological interventions and dehistoricizations can occur not only in the translated text itself, but also in the editorial positioning (Whitfield 89) through introductions and promotions.

8 Acarajé is a famously Afro-Brazilian cuisine, especially in Bahia. Capoeira is a martial art or dance that originated in Brazilian slave populations and has since become popular worldwide. 
The contested textual framings and histories of the oriki become crucial in accounting for Oriki Orixá. The orixás are divinities of West African religions. ${ }^{9}$ According to Omoniyi Afolabi, the composite word orixá combines the nominal ori ("head") with the suffix ixá ("selected") Translating the synecdoche, orixá refers to a person (a "head") that has been "selected," and who now occupies an elevated position. Tellingly, ori does not specify a categorical difference between human and deity: the orixás are humanized, "people selected to be praised." The oriki selected by Risério are addressed to these orixás. Oriki contains the same nominal ori, combined with $k i$, which corresponds to "praise, homage, veneration." However, the same terms of praise may contain elements of denunciation. The oriki transmit an evaluation of a thematized object, not with terms that are positive or negative in isolation, but rather through the juxtaposition of elements.

In turning to the oriki, Risério aims to re-circulate and re-valorize an African aesthetic in Brazil, and frames the poems with extensive essays. Like Afolabi, the translator characterizes the oriki as a montage that poetically juxtaposes attributes and epithets. According to the author, "the oriki is above all a type of montage of attributes of the object it thematizes. An epithetic-ideogrammic construction" (93). Initially, Risério's description corresponds with Afolabi's: the oriki develops through montage rather than through linear movement. In shifting to "an epithetic-ideogrammic construction," however, the oriki is cast as necessarily written, rather than oral. The ideogram is a graphic element that signifies a concept through convention or through visual resemblance to the signified concept. The "ideogrammic" characterization of the oriki, then, presents a paradox: a necessarily written linguistic system applies to a poem that is performed orally, and only exists in script through transcription. Editora Perspectiva's promotional blurb reinforces the decontextualization and recontextualization of the oriki, asserting that "Oriki is a song to call to oneself a Yoruba god (or orixá) through an 'ideogrammic' synthesis of its attributes." Rather than invoking the ideogram as the outcome of an intersemiotic translation, the translator and promoter define the oriki itself as essentially visual.

The curious suggestion of an oral ideogram only coheres in light of Oriki Orixá's "receiving intertext," that is, the network of local texts that allow readers to situate a translation and to establish its meaning (Venuti "Translation" 162). The Brazilian Concrete Poets, especially Augusto and Haroldo de Campos, posited the ideogram as an ideal system for avant-garde poetic experi-

9 These definitions of oriki and orixá follow a conversation with Dr. Omoniyi Afolabi at the University of Texas at Austin, 29 February 2012. 
mentation, following Pound's "ideogrammic method" in The ABC of Reading. In the 1956 "Concretist Manifesto," the Campos brothers and Décio Pignatari equate the innovative concrete poem with the Poundian ideogram: "the concrete poem or ideogram becomes a relational field of funcions [sic]." Through a complex process of dehistoricization, the ideogram as an originally nonwestern writing system becomes superimposed, through the mediations of Pound, the Concrete Poets, and Risério, onto another non-western literary system in the oriki.

Campos's introduction and the editorial promotion conceal layers of dehistoricization and mediation in the construction of the oriki. The editorial positioning of the text contrasts with the positioning of Sàlámi's Mitologia, one of the previous Brazilian Portuguese translations. Mitologia is introduced on the dust jacket and preface by Iyakẹmi Ribeiro. As in Editora Perspectiva's promotion of Oriki Orixá, Ribeiro frames Sàlámi's translation as the recuperation of an African cultural tradition in Brazil. The political stakes of this recuperation, however, diverge. For Ribeiro, Mitologia circumvents the Eurocentric mediations and biases that dominate previous studies of oriki and of African cultural production more generally (11). The "colonial attitude" and

intellectual colonialism are evidenced in the frequently-observed attitude of privileging European or American authors over African authors. As if the African man only ever occupied the role of dancing, singing, worshipping, planting, reaping, establishing social relations and so on, always in the condition of object of great scientific interest for the Europeans or Americans, who are held as true subjects of knowledge.

10

Ribeiro promotes Mitologia as an African-authored decolonial literary text: the translation subverts the hegemonic intellectual practice of Euro-American scholars mediating the circulation of African "objects," while retaining the subject position for themselves.

Whereas Ribeiro situates the translation of the oriki within a history of Euro-American domination of African forms, the framing of Oriki Orixá favors a "transcendental subjectivity" (Venuti Translator's 39) located outside the fraught history of European-African contact. This dehistoricization also operates within the text, dramatized in the poem listed as "Ogum 1" in Oriki Orixá. Before being re-translated in Oriki Orixá, the transcribed and translated Yoruba poem appears in a 1989 anthropological essay by John Pemberton III. The English anthropologist, in turn, had reprinted and re-translated the text from a 1964 translation by George Eaton Simpson. Except for minor differences in 
wording and orthography, the texts of Simpson's and Pemberton III's English translations correspond closely. However, the 1964 version presents the text as fragments from several different poems, from two geographical sources in the Nigerian cities Ibadan and Lalupon. The poems were performed in distinct ceremonies, at different times, by potentially multiple composers. Pemberton III's 1989 version, on the other hand, erroneously presents the text as a single poem from a single source, and in Risério's re-re-translation time and place are absent altogether. In Oriki Orixá, the claiming of the first successful poetic re-creation of oriki (17) rests upon an omission of the histories of textual circulation.

\section{Conclusion}

While Eliot cast Pound as the "inventor of Chinese poetry for our time" (quoted in Tryphonopoulos and Adams 59), Campos celebrates how "Antonio Risério is inventing Yoruba poetry for us" (12, emphasis added). In translating "for our time" as "para nós," the identity of those who count as "us" is left unspecified. The question of inventing Africa for whom has been treated by Patricia de Santana Pinho in Mama Africa: Reinventing Blackness in Bahia. Pinho traces how imagery of Africa is invoked, "invented," and "re-invented" by activists and politicians in Risério's home state of Bahia. Inventions of Africa have provided a set of fraught and contested images for both progressive and conservative causes (3-4). As I have argued here, Oriki Orixá, explicitly framed as an "invention" of an African source literature, acts within these contestations over Brazil's African heritage.

Oriki Orixá blends an avant-garde aesthetic of invenção with an ostensible recovery or resgate of the oriki as a source text of the Brazilian nation. In one sense, the translation's success in bringing a Yoruba text to a Brazilian and international audience challenges Pascale Casanova's problematic dismissal of the translation of non-written literatures such as Yoruba, which "are unknown in the international field and cannot benefit from translation" (289). At the same time, however, the translation's progressive aesthetic accompanies the revival of a discourse of racial exceptionalism in Brazil. In oscillating between affective and political registers, Oriki Orixá reinforces a discursive and literary tradition that mystifies sociopolitical racial inequality through affective cultural celebration.

Oriki Orixá attests to the capacity of translation as a locus within which to query the ideologically motivated manipulation of text and the central yet often hidden power in representing and appropriating a foreign culture. The 
translator paradoxically subsumes oral poetry within the avant-garde ideal of the written "ideogram," contrasting with the anti-Eurocentric project of the previous Brazilian Portuguese translations of the same poems. Just as the ideogram is posited as the product of translation, the process of translation is imagined as an affective encounter that comes to stand in for national race relations. The domestication of the oral text reflects the tradition of cultural appropriation that Isfahani-Hammond terms "white negritude."

In A utopia brasileira, Risério writes that even Brazilian whites are "more African" than North American blacks: "today we can feel at liberty to say that Brazilian whites are, in good part, more 'black' — more 'African,' better statedthan North American blacks" (148). The particularities of the North American slave system severed black Americans' ancestral genealogical and spiritual links to Africa. In contrast, Risério argues, white and black Brazilians share the retention of a "more African" identity. Indicating the exceptionality of the Africanized white Brazilian, Risério protests the cultural translation of constructions of race between North American and Brazilian black movements. In this way, "white negritude" as translational process of domestication and appropriation dovetails with the claim of the Africanization of "os brancos brasileiros." By claiming a more authentic approach to the African sources of cultural elements through a literary translation, Oriki Orixá positions the "Africanized" white translator as the privileged authority of cultural representation.

As Brazilian cultural products increasingly travel in the international imaginary, polemics on the social construction race travel with them. North American perceptions of Brazilian racial constructions, and the converse, offer case studies for exploring modes of cultural translation. Here, I have attempted to illuminate a case in which literary translation echoes and reinforces a powerful racial ideology. More generally, critics can read across literary intertexts, discursive traditions, and ideological polemics. Unexpected corollaries-or productive alternatives - to the dehistoricizing impetus of a text such as Oriki Orixá may emerge in other literary and linguistic traditions. Critical readings attuned to the local forces playing on global circulation can spur rich interrogations of literary ideologies, contestations, and potentialities.

\section{Works Cited}

Afolabi, Omoniyi. Personal Interview. 29 Feb. 2012.

Bassnett, Susan, and Harish Trivedi. Postcolonial Translation:Theory and Practice. London: Routledge, 2012. 
Campos, Augusto, Haroldo de Campos, and Décio Pignatari. "Concrete Poetry: A Manifesto." Augusto de Campos: Site Oficial. UoL, n.d. Web. 12 Jan. 2014.

Casanova, Pascale. "Consecration and Accumulation of Literary Capital: Translation as Unequal Exchange." Translated from French by S. Brownlie. Critical Readings in Translation Studies, ed. Mona Baker. New York: Routledge, 2010. 285-303.

Damrosch, David. What is World Literature? Princeton: Princeton UP, 2003.

Economist. "Affirming a Divide." The Economist, 28 Jan. 2012. Web. 16 Feb. 2015.

"Editora Perspectiva: Oriki Orixá." Editora Perspectiva, Perspectiva, n.d. Web. 15 June. 2015 .

Freyre, Gilberto. The Masters and the Slaves: A Study in the Development of Brazilian Civilization. Trans. Samuel Putnam. New York: Alfred A. Knopf, 1956.

Gil, Gilberto. "Discurso do ministro Gilberto Gil empossando sua equipe no Ministério da Cultura (Minister Gilberto Gil's Speech Introducing his Team in the Ministry of Culture)." Brasilia. Ministério da Cultura-MinC, 15 Jan. 2003. Speech. Web. 15 Feb. 2014.

Gleason, Judith Illsley. Oya: In Praise of an African Goddess. San Francisco: Harper San Francisco, 1992.

Guimarães, Antonio Sérgio Alfredo. "Democracia racial." Cadernos PENEsB. Relações raciais e educação: temas contemporâneos. Niterói: UFF (2002).

Isfahani-Hammond, Alexandra. White Negritude: Race, Writing, and Brazilian Cultural Identity. New York: Macmillan, 2008.

Klobucka, Anna M. "Love Is All You Need: Lusophone Affective Communities after Freyre." Gender, Empire, and Postcolony:Luso-Afro-Brazilian Intersections, eds. Hilary Owen and Anna M. Klobucka. London: Palgrave Macmillan, 2014, 33-47.

Lefevere, André. Translation, History, Culture: A Sourcebook. London: Routledge, 1992. Lima, Jorge de. Poesia completa I. Peru: Univ Catolica Peru, 1997.

Maio, Marcos Chor. “Unesco's Anti-Racist Agenda: Research on Race Relations in Brazil in the 1950s." Paris: Unesco, n.d. Web. 5 Jan. 2016.

Mello Franco, Bernardo. "Em busca do Рів (In Search of the Рів)." Folha de S. Paulo, Folha de São Paulo, 2014, Web. 12 Jan. 2015.

Milton, John, and Paul Bandia. Agents of Translation. Amsterdam and Philadelphia: Benjamins, 2009.

Nascimento, Abdias do. Brazil, Mixture or Massacre?: Essays in the Genocide of a Black People. Dover, MA: Majority Press, 1989.

Padilha, Laura Cavalcante. "Da construção identitária a uma trama de diferenças-Um olhar sobre as literaturas de língua portuguesa (From Identitary Construction to a Story of Differences - a look at Portuguese Language Literatures)." Revista Crítica de Ciências Sociais 73 (2005), 3-28.

Pemberton III, John. "The Dreadful God and the Divine King." Africa's Ogun: Old World and New, ed. Sandra T. Barnes. Bloomington: Indiana UP, 1997, 105-46. 
Pinho, Patricia de Santana. Mama Africa:Reinventing Blackness in Bahia. Durham:Duke UP, 2010.

Pound, Ezra. ABC of Reading. New York: New Directions Publishing, 2010.

Risério, Antonio. A utopia brasileira e os movimentos negros (The Brazilian Utopia and the Black Movements). São Paulo: Editora 34, 2007.

Risério, Antonio. Avant-garde na Bahia (Avant-Garde in Bahia). São Paulo: Instituto Lina Bo e P.M. Bardi, 1995.

Risério, Antonio. Carnaval Ijexá. Brazil: Corrupio, 1981.

Risério, Antonio. Fetiche (Fetish). Salvador: Fundação Casa de Jorge Amado, 1996. Coleção Casa de Palavras.

Risério, Antonio. Oriki Orixá. São Paulo: Editora Perspectiva, 1996. Signos 19.

Risério, Antonio. Uma história da Cidade da Bahia (A History of the City of Bahia). Brazil: Versal Editores, 2004.

Sàlámì, Síkírù. Cânticos dos Orixás na África (Songs of the Orixás in Africa). São Paulo: Editora Oduduwa, 1991.

Sàlámì, Síkírù. Mitologia dos Orixás africanos (Mythology of the African Orixás). São Paulo: Editora Oduduwa, 1990.

Santos, Emanuelle, and Patricia Schor. "Interview with Ella Shohat and Robert Stam: 'Brazil Is not Travelling Enough': On Postcolonial Theory and Analogous CounterCurrents." Portuguese Cultural Studies 4: 1 (2014), 13-40.

Segato, Rita Laura. La nación y sus otros: raza, etnicidad y diversidad religiosa en tiempos de politicas de la identidad (The Nation and its Others: Race, Ethnicity, and Religious Diversity in Times of Identity Politics). Buenos Aires: Prometeo Libros Editorial, 2007.

Stam, Robert, and Ella Shohat. Race in Translation: Culture Wars around the Postcolonial Atlantic. New York: NYU Press, 2012.

Simpson, George Eaton. Yoruba Religion and Medicine in Ibadan. Ibadan: Ibadan UP, 1980.

Telles, Edward E. Race in Another America: The Significance of Skin Color in Brazil. Princeton: Princeton UP, 2014.

Tryphonopoulos, Demetres P., and Stephen Adams, eds. The Ezra Pound Encyclopedia. Westport: Greenwood, 2005.

Tymoczko, Maria. Enlarging Translation, Empowering Translators. New York: Routledge, 2008.

Tymoczko, Maria, and Edwin Gentzler. Translation and Power. Amherst: University of Massachusetts Press, 2002.

Venuti, Lawrence. The Translator's Invisibility: A History of Translation. New York: Routledge, 2008.

Venuti, Lawrence. “Translation, Intertextuality, Interpretation." Romance Studies 27: 3 (2009), 157-173. 
Verger, Pierre. Notes sur le culte des Orisa et Vodun; à Bahia, la Baie de tous les saints, au Brésil et à l'ancienne côte des esclaves en Afrique. Dakar: IFAN, 1957.

White, Steven F. "Reinventing a Sacred Past in Contemporary Afro-Brazilian Poetry: An Introduction." Callaloo 20:1 (1997), 69-82.

Whitfield, Agnes. "Retranslation in a Postcolonial Context: Extra-Textual and IntraTextual Voices in Hubert Aquin's Novel of Québec Independence Prochain Épisode.” Target 27: 1 (2015), 75-93. 